\title{
Nutritional Quality and Health Benefits of Okra (Abelmoschus esculentus): A Review
}

\author{
Habtamu Fekadu Gemede ${ }^{1,4 *}$, Negussie Ratta ${ }^{2}$, Gulelat Desse Haki ${ }^{3}$, Ashagrie Z Woldegiorgis ${ }^{4}$ and Fekadu Beyene \\ ${ }^{1}$ Department of Food Technology and Process Engineering, Wollega University, P.O.Box: 395, Nekemte, Ethiopia \\ ${ }^{2}$ Department of Chemistry, Addis Ababa University, P.O. Box 1176, Addis Ababa, Ethiopia \\ ${ }^{3}$ Department of Food Science and Technology, Botswana Collage of Agriculture, Botswana University, Gaborone, Botswana \\ ${ }^{4}$ Center for Food Science and Nutrition, Addis Ababa University, P.O. Box 1176, Addis Ababa, Ethiopia
}

\begin{abstract}
Okra (Abelmoschus esculentus) is an economically important vegetable crop grown in tropical and sub-tropical parts of the world. This paper was aimed to review nutritional quality and potential health benefits of edible parts of Okra. Okra is a multipurpose crop due to its various uses of the fresh leaves, buds, flowers, pods, stems and seeds. Okra immature fruits, which are consumed as vegetables, can be used in salads, soups and stews, fresh or dried, fried or boiled. It offers mucilaginous consistency after cooking. Often the extract obtained from the fruit is added to different recipes like stews and sauces to increase the consistency. Okra mucilage has medicinal applications when used as a plasma replacement or blood volume expander. The mucilage of okra binds cholesterol and bile acid carrying toxins dumped into it by the liver. Okra seeds are a potential source of oil, with concentrations varying from $20 \%$ to $40 \%$, which consists of linoleic acid up to $47.4 \%$. Okra seed oil is also a rich source of linoleic acid, a polyunsaturated fatty acid essential for human nutrition. Okra has been called "a perfect villager's vegetable" because of its robust nature, dietary fiber, and distinct seed protein balance of both lysine and tryptophan amino acids. The amino acid composition of okra seed protein is comparable to that of soybean and the protein efficiency ratio is higher than that of soybean and the amino acid pattern of the protein renders it an adequate supplement to legume or cereal based diets. Okra seed is known to be rich in high quality protein especially with regards to its content of essential amino acids relative to other plant protein sources. Okra is a powerhouse of valuable nutrients, nearly half of which is soluble fibre in the form of gums and pectins which help to lower serum cholesterol, reducing the risk of heart diseases. The other fraction of Okra is insoluble fibre, which helps to keep the intestinal tract healthy. Okra is also abundant with several carbohydrates, minerals and vitamins, which plays a vital role in human diet and health. Okra is rich in phenolic compounds with important biological properties like quartering and flavonol derivatives, catechin oligomers and hydroxycinnamic derivatives. Okra is also known for being high in antioxidants activity. Okra has several potential health beneficial effects on some of the important human diseases like cardiovascular disease, type 2 diabetes, digestive diseases and some cancers. Overall, Okra is an important vegetable crop with a diverse array of nutritional quality and potential health benefits.
\end{abstract}

Keywords: Okra; Nutritional; Quality; Health; Edible; Oil

\section{Introduction}

Okra (Abelmoschus esculentus) is one of the most widely known and utilized species of the family Malvaceae [1] and an economically important vegetable crop grown in tropical and sub-tropical parts of the world [2-4]. This crop is one of the most widely known and utilized species of the family Malvaceae. Okra plant was previously included in the genus Hibiscus. Later, it was designated to Abelmoschus, which is distinguished from the genus Hibiscus [5]. Okra originated in Ethiopia [6] and was then propagated in North Africa, in the Mediterranean, in Arabia and India by the $12^{\text {th }}$ century BC [7]. Considering the little contact between Ethiopia and the rest of the world within historic times, it is not surprising that little is known about the early history and distribution of okra. The routes by which okra was taken from Ethiopia to North Africa, the eastern Mediterranean, Arabia, India, when are by no means certain [8]. Okra is known by many local names in different parts of the world. It is called lady's finger in England, gumbo in the United States of America, guino-gombo in Spanish, guibeiro in Portuguese and bhindiin India $[9,10]$. In its origin of Ethiopia it is also called Kenkase (Berta), Andeha (Gumuz), Bamia (Oromica/Amharic). The name Okra probabily derives from one of Niger-Congo group of languages (the name for okra in the Twi language is nkuruma) [11]. The term okra was in the use of English by the late 18th century [12]. Okra is suitable for cultivation as a garden crop as well as on large commercial farms [13]. Okra plants are grown commercially in many countries such as India, Japan, Turkey, Iran, Western Africa, Yugoslavia, Bangladesh, Afghanistan, Pakistan, Myanmar, Malaysia, Thailand,
India, Brazil, Ethiopia, Cyprus and in the Southern United States [14]. Okra is a multipurpose crop due to its various uses of the fresh leaves, buds, flowers, pods, stems and seeds [15]. Okra immature fruits (green seed pods), which are consumed as vegetables, can be used in salads, soups and stews, fresh or dried, fried or boiled. It offers mucilaginous consistency after cooking. Often the extract obtained from the fruit is added to different recipes like soups, stews and sauces to increase the consistency. Okra mucilage has medicinal applications when used as a plasma replacement or blood volume expander. The mucilage of okra binds cholesterol and bile acid carrying toxins dumped into it by the liver. The immature pods are also used in making pickle. The entire plant is edible and is used to have several foods $[16,17]$.

Okra seeds are source of oil and protein. Okra seeds have been used on a small scale for oil production. It can be also used as noncaffeinated substitute for coffee. Okra seeds may be roasted and ground to form a caffeine-free substitute for coffee [18]. Okra also has

*Corresonding author: Habtamu Fekadu Gemede, Department of Food Technology and Process Engineering, Wollega University, P.O.Box: 395, Nekemte, Ethiopia, Tel: +251-91-7036925; E-mail: fekadu_habtamu@yahoo.com

Received November 26, 2015; Accepted May 01, 2015; Published May 08, 2015

Citation: Gemede HF, Ratta N, Haki GD, Woldegiorgis AZ, Beyene F (2015) Nutritional Quality and Health Benefits of Okra (Abelmoschus esculentus): A Review. J Food Process Technol 6: 458. doi:10.4172/2157-7110.1000458

Copyright: (c) 2015 Gemede HF, et al. This is an open-access article distributed under the terms of the Creative Commons Attribution License, which permits unrestricted use, distribution, and reproduction in any medium, provided the original author and source are credited. 
industrial applications and is used in confectionary [19]. To promote the use of indigenous vegetables like Okra that have play significant role in mitigate food insecurity and alleviate malnutrition in the country. However, Okra has been considered a minor crop and no attention was paid to its improvement in the international research program in past [20]. On the other hand, the demand for vegetable oils is rapidly increasing due to the growing human population and the expanding oil industry with health promoting oil components, the exploration of some underutilized and newer resources of vegetable oils is of much concern [21]. Okra, which is currently grown mainly as a vegetable crop, has potential for cultivation as an essential oilseed crop because okra seeds contain high amount of oil (20-40\%) [22]. However, there is also no comprehensive literature information regarding characteristics of the oils produced from Okra seeds. Therefore, this review was aimed to assess literature regarding the nutritional quality and potential health benefits of edible parts of Okra (Abelmoschus esculentus) vegetable. The oil compositions of okra seed was also discussed in order to provide further reliable information about health promoting oil components of Okra seeds.

\section{Nutritional composition of okra}

Okra is more a diet food than staple [23]. Okra seeds have been used on a small scale for oil production. Lipid components greatly contribute to the nutritional and sensory value of almost all types of foods. Nature provides a large number of fats that differ in their chemical and functional properties. Four classes of lipids are habitually found in vegetable oils: triacylglycerols, diacylglycerols, polar lipids, and free fatty acids. The fatty acid composition determines the physical properties, stability, and nutritional value of lipids. The most naturally occurring storage lipids are triacylglycerols. Triacylglycerols are natural compounds that consist of saturated and unsaturated fatty acids that differ in the length of their acyl chains and the number and positions of double bonds: saturated, monoenoic, and polyunsaturated fatty acids that differ with respect to detailed fatty acid composition. Monoenoic fatty acids and polyunsaturated fatty acids are structurally distinguished by the presence of repeating methylene units. These units produce an extremely flexible chain that rapidly reorients through conformational states and constitutes an influential group of molecules that promote health [24]. Okra seeds from Greece are a potential source of oil, with concentrations varying from $20 \%$ to $40 \%$, depending on the extraction method. The oil mainly consists of linoleic acid (up to $47.4 \%$ ). Okra seed oil is a rich source of linoleic acid, a polyunsaturated fatty acid essential for human nutrition [25]. Proteins play a particularly important role in human nutrition. The amino acid contents, proportions, and their digestibility by humans characterize a protein's biological value [26] Okra has been called "a perfect villager's vegetable" because of its robust nature, dietary fiber, and distinct seed protein balance of both lysine and tryptophan amino acids (unlike the proteins of cereals and pulses) [27]. The amino acid composition of okra seed protein is comparable to that of soybean and the PER is higher than that of soybean [28] and the amino acid pattern of the protein renders it an adequate supplement to legume or cereal based diets [29]. Okra seed is known to be rich in high quality protein especially with regards to its content of essential amino acids relative to other plant protein sources. Hence, it plays a vital role in the human diet [30]. Okra also contains carbohydrates and vitamins [31-33], and plays a vital role in human diet [34]. Consumption of young immature okra pods is important as fresh fruits, and it can be consumed in different forms. Fruits can be boiled, fried or cooked [35]. The composition of okra pods per $100 \mathrm{~g}$ edible portion $(81 \%$ of the product as purchased, ends trimmed) is: water $88.6 \mathrm{~g}$, energy 144.00 $\mathrm{kJ}$ (36 kcal), protein $2.10 \mathrm{~g}$, carbohydrate $8.20 \mathrm{~g}$, fat $0.20 \mathrm{~g}$, fibre $1.70 \mathrm{~g}$,
Ca $84.00 \mathrm{mg}, \mathrm{P} 90.00 \mathrm{mg}$, Fe $1.20 \mathrm{mg}, \beta$-carotene $185.00 \mu \mathrm{g}$, riboflavin $0.08 \mathrm{mg}$, thiamin $0.04 \mathrm{mg}$, niacin $0.60 \mathrm{mg}$, ascorbic acid $47.00 \mathrm{mg}$. The composition of okra leaves per $100 \mathrm{~g}$ edible portion is: water $81.50 \mathrm{~g}$, energy $235.00 \mathrm{~kJ}(56.00 \mathrm{kcal})$, protein $4.40 \mathrm{~g}$, fat $0.60 \mathrm{~g}$, carbohydrate $11.30 \mathrm{~g}$, fiber $2.10 \mathrm{~g}$, Ca $532.00 \mathrm{mg}, \mathrm{P} 70.00 \mathrm{mg}, \mathrm{Fe} 0.70 \mathrm{mg}$, ascorbic acid $59.00 \mathrm{mg}, \beta$-carotene $385.00 \mu \mathrm{g}$, thiamin $0.25 \mathrm{mg}$, riboflavin $2.80 \mathrm{mg}$, niacin $0.20 \mathrm{mg}$ [36]. Carbohydrates are mainly present in the form of mucilage $[37,38]$. That of young fruits consists of long chain molecules with a molecular weight of about 170,000 made up of sugar units and amino acids. The main components are galactose (25\%), rhamnose (22\%), galacturonic acid (27\%) and amino acids (11\%). The mucilage is highly soluble in water. Its solution in water has an intrinsic viscosity value of about $30 \%$. Potassium, Sodium, Magnesium and Calcium are the principal elements in pods, which contain about $17 \%$ seeds. Presence of Iron, Zink, Manganese and Nickel also has been reported [39]. Fresh pods are low in calories (20 per $100 \mathrm{~g})$, practically no fat, high in fiber, and have several valuable nutrients, including about $30 \%$ of the recommended levels of vitamin C (16 to $29 \mathrm{mg}$ ), 10 to $20 \%$ of folate ( 46 to $88 \mathrm{mg}$ ) and about $5 \%$ of vitamin A (14 to $20 \mathrm{RAE}$ ). Both pod skin (mesocarp) and seeds are excellent source of zinc $(80 \mathrm{mg} / \mathrm{g})$ [40]. Okra seed is mainly composed of oligomeric catechins $(2.5 \mathrm{mg} / \mathrm{g}$ of seeds) and flavonol derivatives ( $3.4 \mathrm{mg} / \mathrm{g}$ of seeds), while the mesocarp is mainly composed of hydroxycinnamic and quercetin derivatives $(0.2$ and $0.3 \mathrm{mg} / \mathrm{g}$ of skins). Pods and seeds are rich in phenolic compounds with important biological properties like quartering derivatives, catechin oligomers and hydroxycinnamic derivatives. These properties, along with the high content of carbohydrates, proteins, glycol-protein, and other dietary elements enhance the importance of this foodstuff in the human diet [41]. Dried okra sauce (pods mixed with other ingredients and regularly consumed in West Africa) does not provide any beta carotene (vitamin A) or retinol [42]. However, fresh okra pods are the most important vegetable source of viscous fiber, an important dietary component to lower cholesterol [43]. Seven-days-old fresh okra pods have the highest concentration of nutrients [44].

\section{Seed as potential edible oil and flour source}

Okra seeds contain about 20 to $40 \%$ oil. The bark fibre is easy to extract. It is white to yellow in colour, strong but rather coarse. Tests conducted in China suggest that an alcohol extract of okra leaves can eliminate oxygen free radicals, alleviate renal tubular-interstitial diseases, reduce proteinuria, and improve renal function. Okra seed can be dried, and the dried seeds are a nutritious material that can be used to prepare vegetable curds, or roasted and ground to be used as coffee additive or substitute [45]. Okra seed oil yield is comparable to most oil seed crops except oil palm and soybean. Moreover, okra seed oil has potential hypocholesterolemic effect. The potential for wide cultivation of okra for edible oil as well as for cake is very high. Okra seed flour could also be used to fortify cereal flour [46]. For example, supplementing maize ogi with okra meal increases protein, ash, oil and fiber content [47]. Okra seed flour has been used to supplement corn flour for a very long time in countries like Egypt to make better quality dough. However, long-term rodent/animal feeding trials would be pertinent before making final recommendations for wider consumption of okra seed flour. The enormous nutritional and other biological activities in the pods and seeds were reported by [48]. The okra pods were reported to have viscous fiber and lower cholesterol content. Okra seeds were determined to have appreciable protein content according to [47]. The variations in polysaccharides found in the mucilage are higher in okra pods according to $[49,50]$. Green vegetables contain valuable chlorophyll [51]. Chlorophyllin as an important component of chlorophyll was reported for enormous 
health benefits. The physiological and biochemical activities of phenolic compounds as antioxidant, anti-inflammatory and anti-microbial were also reported by [52-54] proved the higher values of phenolic and flavonoid values, ratios and distributions in some Bulgarian vegetables and fruits. Generally, fruits and vegetables have shown the basic useful properties especially in providing an excellent health and nutritional qualities in the area of prevention and delay in the onset of chronic diseases and the provision of vitamins and enzymes necessary for proper body function [55].

\section{Mucilage and its potential}

Okra mucilage refers to the thick and slimy substance found in fresh as well as dried pods. Mucilaginous substances are usually concentrated in the pod walls and are chemically acidic polysaccharides associated with proteins and minerals [56]. Although nature of the polysaccharides varies greatly, neutral sugars rhamnose, galactose and galacturonic acid have been reported often. The okra mucilage can be extracted as a viscous gum using various procedures. Such diversity in the extraction procedures seems to contribute to the observed variability in the mucilage chemical composition [57]. Okra mucilage is a renewable and inexpensive source of biodegradable material. Its physical and chemical properties include high water solubility, plasticity, elasticity and viscosity [58]. Most physical and chemical properties are influenced by factors such as temperature, $\mathrm{pH}$, sugar and salt contents, and storage time [59]. Okra mucilage has potential for use as food, non-food products, and medicine. Food applications include use as a whipping agent for reconstituted egg whites, as an additive in the formulation of flour-based adhesives, and as an additive in India for clarifying sugarcane juice. Non-food applications include brightening agents in electro deposition of metals, as a deflocculant in paper and fabric production, and as a protectant to reduce friction in pipe-flow. Polysaccharides can be combined with acrylamide to develop new biodegradable polymeric materials [60]. Potential of mucilage for medicinal applications includes uses as an extender of serum albumin, as tablet binder [61] and as suspending agent in formulations. Okra mucilage is used in Asian medicine as a protective food additive against irritating and inflammatory gastric diseases [62].

\section{Health benefits of okra}

In recent years, increasing attention has been paid to the role of diet in human health [63]. The high intake of plant products is associated with a reduced risk of a number of chronic diseases, such as atherosclerosis and cancer [64]. These beneficial effects have been partly attributed to the compounds which possess antioxidant activity. The major antioxidants of vegetables are vitamins $\mathrm{C}$ and $\mathrm{E}$, carotenoids, and phenolic compounds, especially flavonoids. These antioxidants scavenge radicals and inhibit the chain initiation or break the chain propagation (the second defense line). Vitamin E and carotenoids also contribute to the first defense line against oxidative stress, because they quench singlet oxygen [65]. Flavonoids as well as vitamin $\mathrm{C}$ showed a protective activity to $\alpha$-atocopherol in human LDL, and they can also regenerate vitamin $\mathrm{E}$, from the $\alpha$-chromanoxy radical [66]. Nutrient antioxidants may act together to reduce reactive oxygen spieces level more effectively than single dietary antioxidants, because they can function as synergists [67]. In addition, a mixture containing both water-soluble and lipid-soluble antioxidants is capable of quenching free radicals in both aqueous and lipid phases [68]. For example, with the liposome oxidation method, the activity of combination of quercetin or catechins plus $\alpha$-tocopherol was significantly higher than the sum of the individual activities. Combinations of $\alpha$-tocopherol or vitamin C plus phenolic compounds also provided synergistic effects in human erythrocyte membrane ghosts and phosphatidylcholine liposome systems [69]. Okra seed is rich in protein and unsaturated fatty acids such as linoleic acid. In some countries, okra also is used in folk medicine as antiulcerogenic, gastroprotective, diuretic agents [70]. However, little information on antioxidant capabilities of major phenolic compounds from okra seed is available. Okra is also a popular health food due to its high fiber, vitamin C, and folate content. Okra is also a good source of calcium and potassium. Okra pod contains thick slimy polysaccharides, which are used to thicken soups and stews, as an egg white substitute, and as a fat substitute in chocolate bar cookies and in chocolate frozen dairy dessert. Okra is also known for being high in antioxidants activity with different parts of the plant [71,72] Atawodi has reported in vitro antioxidant assay of methanol extract of okra fruits. They have done antioxidant/radical scavenging activities by xanthine oxidase and 2-deoxyguanosine methods and reported 50\% inhibitory concentration values of 25 and $43 \mathrm{ml}$. In addition, Arapitsas reported that Okra seed is rich in Phenolic compounds, mainly composed of flavonol derivatives and oligomeric catechins. According to Khomsug [73] total phenolic content of pulped and seeds of okra extracts as 10.75 $\pm 0.02 \mathrm{mg} \mathrm{GAE} / 100 \mathrm{~g}$ extract and $142.48 \pm 0.02 \mathrm{mg} \mathrm{GAE} / 100 \mathrm{~g}$ extract which corresponds with scavenging activities. Besides they have also found procycanidin B2 as predominant phenolic compound followed by procycanidin $\mathrm{B} 1$ and rutin in seeds. In pulped seed catechin, procycanidin $\mathrm{B} 2$, epicatechin and rutin are reported to be present. It is quite important to the see that roasting $\left(1600^{\circ} \mathrm{C}\right.$ for $10-60$ minutes) increased the nutrient composition and antioxidant activity of the seeds whereas pre-treatment (soaking and blanching) increased the nutrient composition, but decreases antioxidant activity $[74,75]$. Ansari reported Okra extract as in vitronon-enzymatic inhibitior of lipid peroxidation in liposomes. A. esculentus peel and seed powder contains significant in vivo antioxidant property in streptozotocin-induced diabetic rats. Administration of different doses of peel and seed powder significantly increased liver, kidney and pancreas superoxide dismutase, catalase, glutathione peroxidase, reduced glutathione levels and decreased thiobarbituric acid reactive substances $($ TBARS $)(\mathrm{P}<0.001)$ levels in diabetic rats compared to diabetic control rats [76]. Liao has done a comparative analysis of total phenolics and total flavonoids and antioxidant ability of different organs (flower, fruit, leaf, and seed) and different enrichment fractions of water extracts of the A. esculentus plant. They confirmed fruitful presence of total phenolics and total flavonoids related to antioxidant ability in all the extracts of the plant organs although percentage varied. In flower of okra highest amount of total phenolics and totalflavonoids were found. This data suggests Okra as a good contributor to the antioxidant status and promising chemopreventive agent as described in several traditional medicines for human race. Okra is abundant with several vitamins, minerals, and nutrients that handles the health advantages the plant provides.

Here are a few of okra's health advantages:

- Okra contain high fiber, which "helps to stabilize blood sugar by regulating the rate at which sugar is absorbed from the intestinal tract". Because of fiber along with other nutrition, okra shows useful for minimizing blood sugar levels within the body, assisting along with diabetes. The fiber likewise helps support blood sugar levels level simply by slowing down sugar assimilation through the intestines [77]. The frequent usage of okra might help avoid kidney disease. Within the research, "those who consumed okra every day decreased clinical indications of kidney damage a lot more than the ones that simply consumed a diabetic diet." This ties along with diabetes, as almost $50 \%$ of kidney disease cases are generated by diabetes [78]. 
- Okra is used to treat digestive issues. The polysaccharides present in immature okra pods possessed considerable antiadhesive properties (i.e. they help remove the adhesive between bacteria and stomach tissue, preventing the cultures from spreading). Okra's polysaccharides were particularly effective at inhibiting the adhesion of Helicobacter pylori, a bacterium that dwells in the stomach and can cause gastritis and gastric ulcers if left unchecked. Therefore, eating more okra can keep our stomach clean and create an environment that prevents destructive cultures from flourishing [79]. Okra is used to supports colon health. It smoothly sails down our colon, absorbing all toxins and excess water in its path. Okra is filled with dietary fiber that is required for colon health and digestive health all together. The fiber Okra offers helps to cleanse the intestinal system, letting the colon to operate at higher amounts of effectiveness. In addition, the vitamin A plays a role in wholesome mucous membranes, assisting the digestive system to function adequately [80].

- Okra is used to promote healthy skin and blood. One hundred grams of okra also contain approximately 27 percent of our RDI of vitamin $\mathrm{C}$ and 50 percent of our RDI of vitamin $\mathrm{K}$. Vitamin $\mathrm{C}$ is, of course, an essential antioxidant that aids in the growth and repair of bodily tissues. For this reason, eating more okra can rejuvenate our skin and hair, and also shield us from degenerative diseases associated with long-term free radical damage. Vitamin $\mathrm{K}$, on the other hand, plays an important role in blood clot formation. If you suffer from regular nosebleeds, bleeding gums, heavy menstrual bleeding, or easy bruising, your blood might be too thin. Consider adding more vitamin K-rich foods like okra to your diet to improve your blood's ability to coagulate [81].

- Okra is used to promotes a healthy of the pregnancy. An incredibly essential B vitamin for creating and maintaining new cells, foliate is a vital substance for optimum pregnancy. The vitamin aids in preventing birth defects just like spina bifida and enables the baby to develop completely. Vitamin $\mathrm{C}$ is additionally required for baby development. Okra is full of both foliate and vitamin C. The high quantity of foliate included in the okra is helpful for the fetus while pregnant. Foliate is a vital nutrient that increases the growth and development of the fetus brain. The high quantity of folic acid within okra performs a huge role within the neural tube formation of the fetus through the fourth to the 12 th week of pregnancy [82].

- Okra is used to improves heart health. The soluble fiber within okra helps you to reduce serum cholesterol and therefore decreases the chance of cardiovascular disease. Consuming okra is an efficient method to manage the body's cholesterol level. Okra is additionally loaded with pectin that can help in reducing high blood cholesterol simply by modifying the creation of bile within the intestines. Okra is also used to improves good eyesight. The okra pods are fantastic options for Vitamin A and also beta carotene that are both important nourishment for sustaining an excellent eye-sight along with healthy skin. Additionally, these types of important nourishment also assist inhibits eye associated illnesses along with problems on the skin. Okra is better ingested when joined along with other healthy veggies. Consuming okra has truly numerous advantages, simply bear in mind to eat natural veggies as opposed to processed veggies.

- Okra is used to controls the body's cholesterol level. There are numerous significant illnesses related to high cholesterol level of the entire body. Managing the body's cholesterol level is nearly difficult because it's hard to avoid foods loaded with cholesterol content. One of the better health advantages of consuming okra is definitely the powerful management of the human body's high cholesterol level. This healthy vegetable is beneficial in slimming down and also decreasing cholesterol therefore keeps a healthy and also low cholesterol body. Okra have been taken advantage by diet advisors due to these qualities.

- Generally, okra is used to stabilize blood sugar by regulating the rate at which sugar is absorbed from the intestinal tract. It is a good vegetable for those feeling weak, exhausted, and suffering from depression and it is also used in ulcers, lung inflammation, sore throat as well as irritable bowel. Okra is good for asthma patients and it also normalizes blood sugar and cholesterol levels. Previous studies reported that okra polysaccharide possesses anticomplementary and hypoglycemic activity in normal mice [83]. Also, okra polysaccharide lowers cholesterol level in blood and may prevent cancer by its ability to bind bile acids. Additionally, Okra seed possess blood glucose normalization and lipid profiles lowering action in diabetic condition [84].

\section{Conclusion}

The information presented here shows the potential nutritional importance of Okra and its role in improved nutrition and health. It is an affordable source of protein, carbohydrates, minerals and vitamins, dietary fibre and health promoting fatty acids. Scientific studies provide some evidence to support the potential beneficial effects of Okra components in lowering the risk for various chronic diseases, although information pertaining to the role of edible plant parts of Okra in disease prevention and the mechanisms of action are limited to date. This is due to the complex nature of disease etiology and various factors impacting their occurrence. It is imperative the scientific community continues to unravel the mechanisms involved in disease prevention and determine how food bio-actives from such foods as Okra can influence human health. Further research, needs to be performed to provide compelling evidence for the direct health benefits of Okra consumption. Therefore, promoting the consumption of traditional vegetables such as Okra could provide cheap sources of macro and micronutrients and mineral elements that can improve the nutritional status of resource-poor subsistence farmers in the area in particular and in Ethiopia in general. Furthermore, this vegetable can also be used as an indispensable tool when it comes to reducing the prevalence of malnutrition, especially among resource-constrained urban households in addition to rural household. Consumption of Okra by both low-income and high-income groups can also used as a means of dietary diversification approach.

\section{References}

1. Naveed A, Khan AA, Khan IA (2009) Generation mean analysis of water stress tolerance in okra (Abelmoschus esculentus L.). Pak J Bot 41: 195-205.

2. Oyelade OJ, Ade-Omowaye BIO, Adeomi VF (2003) Influence of variety on protein, fat contents and some physical characteristics of okra seeds. J Food Eng 57: 111-114.

3. Andras CD, Simandi B, Orsi F, Lambrou C, Tatla DM, et al. (2005) Supercritical carbon dioxide extraction of Okra (Hibiscus esculentus L.) seeds. J Sci Food Agric 85: 1415-1419.

4. Saifullah M, Rabbani MG (2009) Evaluation and characterization of okra (Abelmoschus esculentus L. Moench.) genotypes. SAARC J Agric 7: 91-98.

5. Aladele SE, Ariyo OJ, Lapena Rde (2008) Genetic relationships among West African okra (Abelmoschuscaillei) and Asian genotypes (Abelmoschus esculentus) using RAPD. African Journal of Biotechnology 7: 1426-1431.

6. Sathish D, Eswar A (2013) A Review on: Abelmoschus esculentus (Okra). Int Res J Pharm App Sci 3: 129-132.

7. Nzikou J, Mvoula-Tsieri M, Matouba E (2006) A study on gumbo seed grown in Congo Brazzaville for its food and industrial applications. African Journal of Biotechnology 5: 2469-2475. 
Citation: Gemede HF, Ratta N, Haki GD, Woldegiorgis AZ, Beyene F (2015) Nutritional Quality and Health Benefits of Okra (Abelmoschus esculentus): A Review. J Food Process Technol 6: 458. doi:10.4172/2157-7110.1000458

8. Tindall HD (1983) Vegetables in the tropics. Macmillan Education Limited, London, UK.

9. Ndunguru J, Rajabu AC (2004) Effect of okra mosaic virus disease on the above-ground morphological yield components of okra in Tanzania. Scienta Horticulturae 99: 225-235.

10. Benchasr S (2012) Okra (Abelmoschus esculentus (L.) Moench) as a Valuable Vegetable of the World. Ratar Povrt 49: 105-112.

11. Benjawan C, Chutichudet $P$, Kaewsit S (2007) Effect of green manures on growth yield and quality of green okra (Abelmoschus esculentusL) har lium cultivar. Pakistan J Biological Sci 10: 1028-1035.

12. Arapitsas $P$ (2008) Identification and quantification of polyphenolic compounds from okra seeds and skins. Food Chem 110: 1041-1045.

13. Rubatzky VE, Yamaguchi M (1997) World vegetables: principles, production, and nutritive values. Chapman and Hall, New York, USA.

14. Qhureshi Z (2007) Breeding investigation in bhendi (Abelmoschus esculentus (L.) Moench). Master Thesis, University of Agriculture Sciences, GKVK, Bangalore, India.

15. Mihretu Y, Wayessa G, Adugna D (2014) Multivariate Analysis among Okra (Abelmoschus esculentus L.) Moench) Collection in South Western Ethiopia. Journal of Plant Sciences 9: 43-50.

16. Madison D (2008) Renewing America's Food Traditions. Chelsea Green Publishing.

17. Maramag RP (2013) Diuretic potential of Capsicum. frutescens L, Corchorus oliturius L, Abelmoschus esculentus L. Asian journal of natural and applied science 2: 60-69.

18. Calisir S, Yildiz MU (2005) A study on some physico-chemical properties of Turkeyokra (Hibiscus esculenta) seeds. Journal of Food Engineering 68: 73-78.

19. Adetuyi FO, Osagie AU, Adekunle AT (2011) Nutrient, antinutrient, mineral and zinc bioavailability of okra Abelmoschus esculentus (L) Moench Variety. Am J Food Nutr 1: 49-54.

20. Sanjeet K, Sokona D, Adamou H, Alain R, Dov P, et al. (2010) Okra (Abelmoschus spp.) in West and Central Africa: Potential and progress on its improvement. African Journal of Agricultural Research 25: 3590-3598.

21. Schalau J (2002) Backyard Gardener.

22. MEF (2013) Biology of Okra. Series of crop specific biology document. Ministry of Environmental and Forest Government of India.

23. National Research Council (2006) "Okra". Lost Crops of Africa: Vegetables. Lost Crops of Africa. National Academies Press.

24. Vermerris W, Nicholson R (2006) Phenolic Compound Biochemistry, Springer Dordrecht, The Netherlands.

25. Savello PA, Martins F, Hull W (1980) Nutrition composition of okra seed meals. J Agric Food Chem 28: 1163-1166.

26. Ewa C, Agnieszka G, Adametal F (2011) "The content of protein and of amino acids in Jerusalem artichoke tubers (Helianthus tuberosus $L$ ) of red variety Rote Zonenkugel". Acta Scientiarum Polonorum, Technologia Alimentaria 10 433-441.

27. Holser R, Bost G (2004) Hybrid Hibiscus seed oil compositions. Journal of the American Oil Chemists' Society 81: 795-797.

28. Adetuyi F, Ajala L, Ibrahim T (2012) Effect of the addition of defatted okra seed (abelmoschus esculentus) flour on the chemical composition, functional properties and zn bioavailability of plantain (musa paradisiacal linn) flour 2 69-82.

29. Ndangui CB, Kimbonguila A, Nzikou JM, Matos L, Pambou NPG, et al. (2010) Nutritive Composition and Properties Physico-chemical of gumbo(Abelmoschus esculentu S L.) Seed and Oil. Research Journal of Environmentaland Earth Sciences 2: 49-54

30. Farinde A, Owolarafe O, Ogungbemi I (2007) An overview of production, processing, marketing and utilisation of okra in egbedore local government area of Osun State, Nigeria. Agricultural Engineering 4: 1-17.

31. Owolarafe OK, Shotonde HO (2004) Some physical properties of fresh okra fruit. J Food Engin 63: 299-302.

32. Gopalan C, Sastri SBV, Balasubramanian S (2007) Nutritive value of Indian foods. National Institute of Nutrition (NIN), ICMR, India.
33. Dilruba S, Hasanuzzaman M, Karim R, Nahar K (2009) Yield response of okra to different sowing time and application of growth hormones. J Hortic Sci Ornamental Plants 1: 10-14.

34. Kahlon TS, Chapman MH, Smith GE (2007) In vitro binding of bile acids by okra beets asparagus eggplant turnips green beans carrots and cauliflower. Food Chem 103: 676-680.

35. Akintoye HA, Adebayo AG, Aina OO (2011) Growth and yield response of okra intercropped with live mulches. Asian J Agric Res. 5: 146-153.

36. Varmudy V (2011) Marking survey need to boost okra exports. Department of economics, Vivekananda College, Puttur, Karnataka, India.

37. Liu IM, Liou SS, Lan TW, Hsu FL, Cheng JT (2005) Myricetin as the active principle of Abelmoschus moschatusto lower plasma glucosein streptozotocininduced diabetic rats. Planta Medica 71: 617-621.

38. Kumar R, Patil MB, Patil SR, Paschapur MS (2009) Evaluation of Abelmoschus esculentus mucilage as paracetamol suspension. Intl. J Pharm Tech Res 1: 658-665.

39. Moyin-Jesu El (2007) Use of plant residues for improving soil fertility pod nutrients root growth and pod weight of okra. Abelmoschus esculentum L. Bioresour Tech 98: 2057-2064.

40. Cook JA, Jagt DJ, Pastuszyn A, Mounkaila G, Glew RS, et al. (2000) Nutrient and chemical composition of 13 wild plant foods of Niger. J Food Comp Anal 13: 83-92.

41. Manach C, Williamson G, Morand C, ScalbertA, Remesy C (2005) Bioavailability and bioefficacy of polyphenols in humans. Amer. J. Clinical Nutrit 81: 230-242.

42. Avallone S, Tiemtore TWE, Rivier CM, Treche S (2008) Nutritional value of six multi-ingredient sauces from Burkina Faso. J. Food Comp Anal 21: 553-558.

43. Kendall CWC, Jenkins DJA (2004) A dietary portfolio: maximal reduction of low-density lipoprotein cholesterol with diet. Current Atherosclerosis Reports 6: 492-498.

44. Agbo AE, Gnakri D, Beugre GM, Fondio L, Kouame C (2008) Maturity degree of four okra fruit varieties and their nutrients composition. Elect. J Food Plant Chem 5: 1-4.

45. Moekchantuk T, Kumar P (2004) Export Okra production in Thailand. Intercountry programme for vegetable IPM in South and SE Asia phase II. Food and Agriculture Organization of the United Nations, Bangkok, Thailand.

46. Adelakun OE, Oyelade OJ, Ade-Omowaye BIO, Adeyemi IA, Vande M (2009) Influence of pre-treatment on yield, chemical and antioxidant properties of Nigerian okra seed (Abelmoschus esculentus Moench). Food Chem Toxicol 47: 657-661.

47. Akingbala JO, Akinwande BA, Uzo-Peters PI (2003) Effects of color and flavo changes on acceptability of ogi supplemented with okra seed meals. Plant Foods Human Nutr 58: 1-9

48. Kumar S, Dagnoko S, Haougui S, Ratnadass, A, Pasternak D, et al. (2010) Okra (Abelmoschus spp.) in West and Central Africa: potential and progress on its improvement. Afr J Agric Res 25: 3590-3598.

49. Hirose K, Endo K, Hasegawa K (2004) A convenient synthesis of lepidimoide from okra mucilage and its growth promoting activity in hypocotyls. Carbohydr Poly 339: 9-19.

50. Sengkhamparn N, Verhoef R, Schols HA, Sajjaanantakul T, Voragen AG (2009) Characterisation of cell wall polysaccharides from okra (Abelmoschus esculentus (L.) Moench) Carbohydr Res 344: 1824-1832.

51. Ebermann R, Alth G, Kreitner M, Kubin A (1996) Natural products derived from plants as potential drugs for the photodynamic destruction of tumor cells. J Photochem Photobiol B 36: 95-97.

52. Ali A, Deokule SS (2008) Comparison of phenolic compounds of some edible plant of Iran and India. Pak J Nutr 7: 582-585.

53. Middleton E (2000) The effects of plant flavonoids on mammalian cells: Implications for inflammation, heart disease and cancer. Pharm Rev 52: 673751.

54. Marinova D, Ribarova F, Atanassova M (2005) Total phenolics and tota flavonoids in Bulgarian fruits and vegetables. J Univ Chem Technol Metallur 40: $255-260$.

55. Aman R, Schieber A, Carle R (2005) Effects of heating and illumination on 
Citation: Gemede HF, Ratta N, Haki GD, Woldegiorgis AZ, Beyene F (2015) Nutritional Quality and Health Benefits of Okra (Abelmoschus esculentus): A Review. J Food Process Technol 6: 458. doi:10.4172/2157-7110.1000458

trans-cis isomerization and degradation of $\beta$-carotene and lutein in isolated spinach chloroplasts. J Agric Food Chem 53: 9512-9518.

56. Woolfe ML, Martin FC, Otchere G (1977) Studies on the mucilages extracted from okra fruits (Hibiscus esculentus L.) and baobab leaves (Adansonia digitata L.). J Sci Food Agric 28: 519-529.

57. Ndjouenkeu R, Goycoolea FM, Morris ER, Akingbala JO (1996) Rheology of okra (Hibiscus esculentus L.) and dika nut (Irvinia gabonensis) polysaccharides. Carbohydrate Polymers 29: 263-269.

58. BeMiller JN, Whistler RL, Barkalow DG, Chen CC (1993) Aloea, chia, flax seed, okra, psyllium seed, quince seed, and tamarin gums. Academic Press, NewYork.

59. Bhat UR, Tharanathan RN (1987) Functional properties of okra (Hibiscus esculentus) mucilage. Starch 39: 165-167.

60. Mishra A, Clark JH, Pal S (2008) Modification of okra mucilage with acrylamide: synthesis, characterization, and swelling behavior. Carbohydr Poly 72: 608615.

61. Ofoefule SI, Chukwu AN, Anayakoha A, Ebebe IM (2001) Application of Abelmoschus esculentus in solid dosage forms 1: use as binder for poorly water soluble drug. Indian J Pharm Sci 63: 234-238.

62. Lengsfeld C, Titgemeyer F, Faller G, Hensel A (2004) Glycosylated compounds from okra inhibit adhesion of Helicobacter pyroli to human gastric mucosa. J Agric Food Chem 52: 1495-1503.

63. Ohr LM (2004) Dietary antioxidants. Food Technology 58: 67-74.

64. Gosslau A, Chen KY (2004) Nutraceuticals, apoptosis, and disease prevention. Nutrition, 20: 95-102.

65. Krinsky NI (2001) Carotenoids as antioxidants. Nutrition 17: 815-817.

66. Davey MW, Van Montagu M, Inze D, Sanmartin M, Kanellis A, et al. (2000) Plant L-ascorbic acid: Chemistry, function, metabolism, bioavailability and effects of processing. Journal of the Science of Food and Agriculture 80: 825-860.

67. Rossetto M, Vanzani P, Mattivi F, Lunelli M, Scarpa M, et al. (2002) Synergistic antioxidant effect of catechin and malvidin 3-glucoside on free radical-initiated peroxidation of linoleic acid in micelles. Archives of Biochemistry and Biophysics 408: 239-245.

68. Trombino S, Serini S, Di Nicuolo F, Celleno L, Ando S, et al. (2004) Antioxidant effect of ferulic acid in isolated membranes and intact cells. Journal of Agriculture and Food Chemistry 52: 2411-2420.

69. Liao KI, Yin MCh (2000) Individual and combined antioxidant effects of seven phenolic agents in human. Journal of Agriculture and Food Chemistry 48: 22662270.

70. Gurbuz I (2003) Antiulcerogenic activity of some plants used as folk remedy in Turkey. J Ethnopharmacol 88: 93-97.
71. Shui G, Peng LL (2004) An improved method for the analysis of major antioxidants of Hibiscus esculentus Linn. Journal of Chromatography A 1048: 17-24.

72. Atawodi SE, Atawodi JC, Idakwo GA, Pfundstein B, Haubner R, et al. (2009) Polyphenol composition and antioxidant potential. J Med Food 12: 1316-1320

73. Khomsug $\mathrm{P}$, Thongjaroenbuangam W, Pakdeenarong N, Suttajit M, Chantiratiku $P(2010)$ Antioxidative Activities and Phenolic Content of Extracts from Okra (Abelmoschus esculentus L.). Research Journal of Biological Sciences 5: 310313.

74. Adelakun OE, Ade-Omowaye BIO, Adeyemi IA, Van De Venter M (2010) Functional properties and mineral contents of a Nigerian okra seed (Abelmoschus esculentus Moench) flour as influenced by pretreatment. Journal of Food Technology 8: 39-45.

75. Ansari NM, Houlihan L, Hussain B, Pieroni A (2005) Antioxidant activity of five vegetables traditionally consumed by south-Asian migrants in Bradford Yorkshire, UK. Phytotherapy Research 19: 907-911.

76. Liao H, Liu H, Yuan K (2012) A new flavonol glycoside from the Abelmoschus esculentus Linn. Pharmagnosy Magazine 8: 12-15.

77. Ngoc T, Ngo N, Van T, Phung V (2008) Hypolipidemic effect of extracts from Abelmoschus esculentus L. (Malvaceae) on Tyloxapol-induced hyperlipidemia in mice. Warasan Phesatchasat 35: 42-46.

78. Lengsfeld C, Titgemeyer F, Faller G, Hensel A (2004) Glycosylated compounds from okra inhibit adhesion of Helicobacter pylori to human gastric mucosa. $J$ Agric Food Chem 52: 1495-1503.

79. Messing J, Thöle C, Niehues M, Shevtsova A, Glocker E, et al. (2014) Antiadhesive properties of Abelmoschus esculentus (Okra) immature fruit extract against Helicobacter pylori adhesion. PLoS One.

80. Georgiadisa N, Ritzoulisa C, Siouraa G, Kornezoua P, Vasiliadoub C, et al (2011) Contribution of okra extracts to the stability and rheology of oil-in-water emulsions. Food Hydrocolloids 25: 991-999.

81. Bakre LG, Jaiyeoba KT (2009) Effects of drying methods on the physicochemical and compressional characteristics of Okra powder and the release properties of its metronidazole tablet formulation. Arch Pharm Res 32: 259-267.

82. Zaharuddin ND, Noordin MI, Kadivar Ali (2014) The Use of Hibiscus esculentus(Okra) Gum in Sustaining the Release of Propranolol Hydrochloride in a Solid Oral Dosage Form. Biomed Res Int.

83. Tomoda M, Shimizu N, Gonda R, Kanari M, Yamada H, et al. (1989) Anticomplementary and hypoglycemic activity of okra and hibiscus mucilage. Carbohydr Res 190: 323-328.

84. Sabitha V, Ramachandran S, Naveen KR, Panneerselvam K (2011) Antidiabetic and antihyperlipidemic potential of Abelmoschus esculentus (L.) Moench. in streptozotocin-induced diabetic rats. J Pharm Bioallied Sci 3: 397-402. 